\title{
THE SANTA TEREZINHA DE GOIÁS EMERALD DEPOSIT
}

By I. P. Cassedanne and D. A. Sauer

The Santa Terezinha de Goiás emerald deposit, currently the most important source of emeralds in Brazil, lies northwest of Brasilia, in the State of Goiás. The emeralds, most of which are stones of a carat or less, occur in a talc schist layer intersected by pegmatite. The emeralds are recovered by independent miners via trenches, pits, and tunnels at two prospects: Trecho Novo and Trecho Velho. The grade of the ore is: 1 to 6 parts of emeralds to 10,000 parts of ore. The density of the gems is 2.70; the refractive indexes are 1.580 and 1.588, with greenish dark blue/yellowish pale green pleochroism. The spectrum is typical, with two strong lines and two partial absorption bands; there is no fluorescence; pyrite and chromite are the most typical inclusions,. with calcite crystals present in minor amounts.

\section{ABOUT THE AUTHORS}

Dr. Cassedanne is professor of mineralogy at the Geosciences Institute of the Federal University of Rio de Janeiro, Brazil; and Mr. Saver is director of Lapidação Amsterdam, S.A., Amsterdam Sauer, Rio de Janeiro, Brazil.

(c) 1984 Gemological Institute of America
7 he search for emeralds has been the primary moti1 vation for many expeditions in to the interior of Brazil, all with the hope of discovering emerald deposits as rich as those found in the Colombian Andes. Occurrences of emerald were noted early in this century, but none proved to be commercially important. Finally, in 1963, the first major emerald deposit was discovered in the São Francisco river valley, in the state of Bahia. Known as the Salininha deposit, it produced about 300 pounds $(135 \mathrm{~kg}$ ) of emeralds before it was exhausted. Today, the mine site is flooded by the waters behind the Sobradinho dam. Immediately after this discovery, in 1963-1964, a large emerald field was found at Carnaiba, also in Bahia. The output from the Camaiba mines, which are still active, eventually placed Brazil among the world's leading producers of emerald. This position was reinforced by the opening, in 1978, of the Belmont mine near Itabira, Minas Gerais. However, it was the discovery in 1981 of the Santa Terezinha emerald deposit in Goias that consolidated Brazil's position as a leading producer of emeralds (figure 1).

Even though a fourth deposit, called Socotó, has since been found near Carnaiba, it has not proved as important as the Santa Terezinha mine, which currently reigns as the center for emerald production in Brazil and yet about which little has been published. We propose, therefore, to describe the Santa Terezinha emerald deposit, including the geology, occurrence, mining methods, and gemological aspects of the stones produced.

\section{LOCATION AND ACCESS}

The Santa Terezinha emerald deposit is $230 \mathrm{~km}$ (143 mi.) northwest of Brasília, the federal capital, and about 275 $\mathrm{km}$ (170 mi.) north of Goiania, the capital of the state of Goiás. Approximate longitude and latitude are $49^{\circ} 20^{\prime} \mathrm{W}$ and $14^{\circ} 15^{\prime} \mathrm{S}$ (figure 2 ).

Santa Terezinha is a small town that has developed 


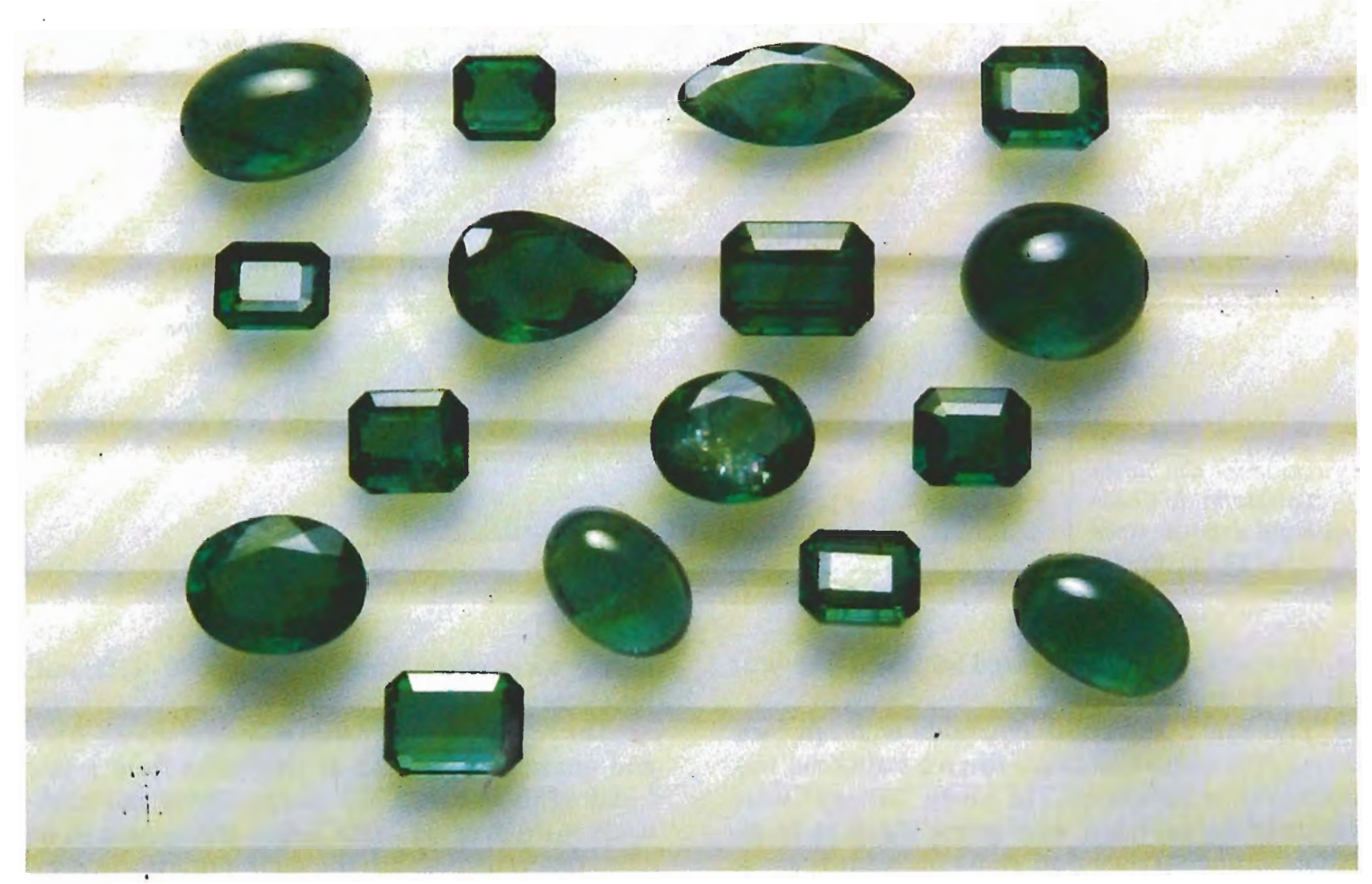

Figure 1. An assortment of fine faceted and cabochon emeralds from Santa Terezinha de Goiás, Brazil.

with the mine. It can be easily reached by either land or air from Brasília or Goiânia. By land, the first two-thirds of the trip is made on the paved Belém-Brasília highway, via Anápolis. The remaining $85 \mathrm{~km}$ to Santa Terezinha, however, must be taken over an unpaved road (in good condition during the dry season) that passes through the towns of Itapaci and Pilar de Goias. Access to the mine site is via a good north-south road that crosses Rio do Peixe valley, a little over $20 \mathrm{~km}$.

The city itself is situated on a large, partially eroded lateritic plateau at about $380 \mathrm{~m}(1,250 \mathrm{ft}$.) elevation. The main river in the region is the CrixásAçu, which flows into the Araguaia, and eventually empties into the Amazon.

Originally, the area's vegetation consisted of cerrado, a low evergreen forest interspersed with high grass. Tropical vegetation occurs intermittently along the creeks, forming gallery-like forests. Much of the land is now under cultivation, and the original virgin forests have been replaced by open areas of grass or crops. This area has a typical monsoon climate: heavy rains occur from December through March, and the rest of the year is very dry.

\section{HISTORY OF MINING IN SANTA TEREZINHA}

Since 1920, emeralds have been produced sporadically in the state of Goiás, but only in very small quantities (Gonçalves, 1949). The best-known deposit is at Fazenda das Lages, near Itaberai, 34 $\mathrm{km}$ southeast of the town of Goias and south of Santa Terezinha (Leinz and Leonardos, 1959). In 1966, a joint venture between Cia Itabras de Mineração and the mine owners produced $15 \mathrm{~kg}$ of emeralds of medium-low quality from a colluvial deposit.

In 1974, the so-called Serra Dourada deposit was discovered $36 \mathrm{~km}$ from Minaçu (Garimpo de Pela Emal, east-northeast of Santa Terezinha. A small emerald production from pegmatites injected 


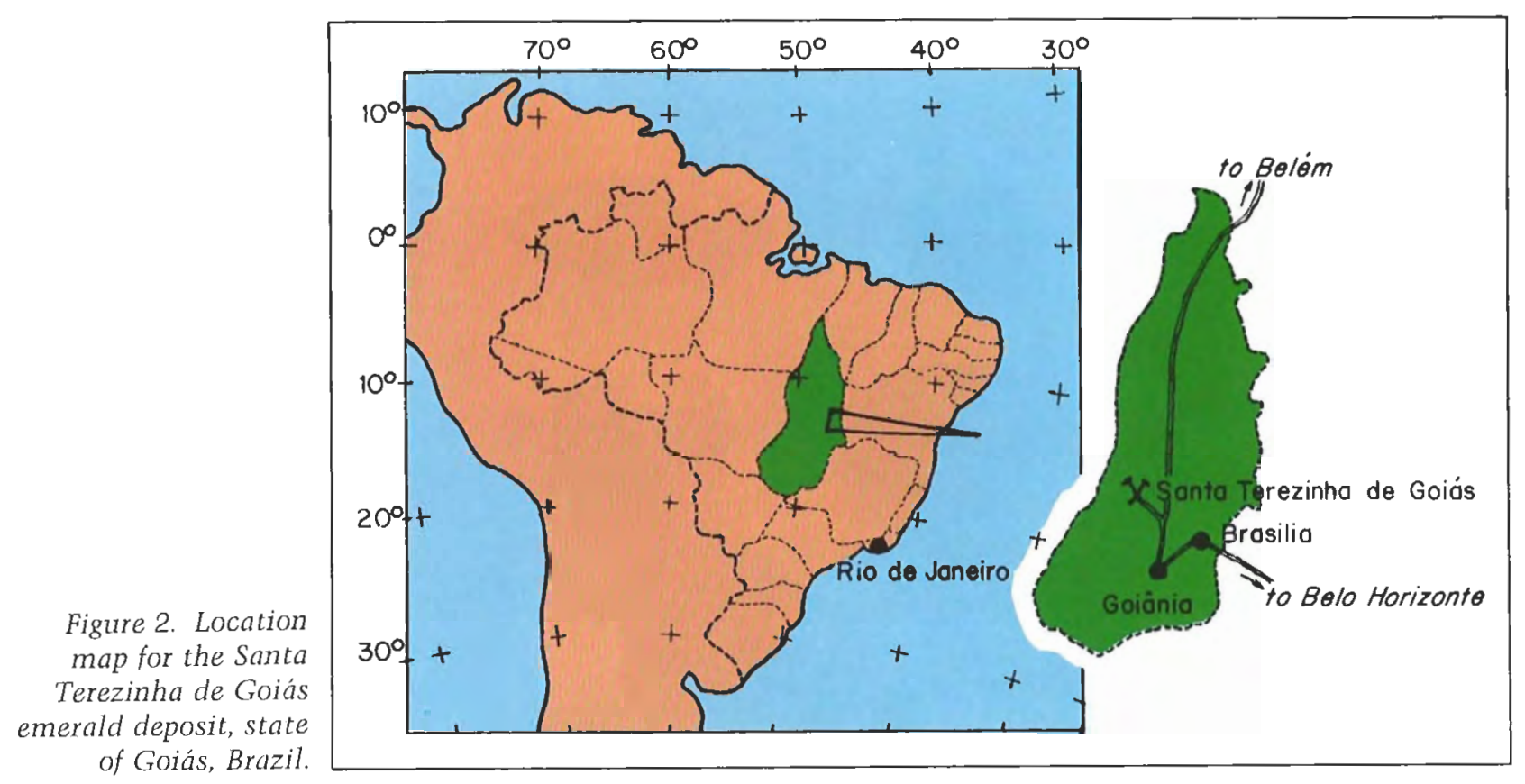

in mica schists was supported for about one year (de Souza and Zalán, 1977).

The Santa Terezinha emeralds were, in fact, discovered some years ago, when a farm road was opened by a bulldozer. The green "stones" were collected by children who threw them at birds. Nobody thought they were gems, probably because the crystals collected on the ground were heavily stained by iron oxides. In March 1981, however, a gem dealer from Governador Valadares identified the true nature of the stones. Immediately there was a rush of garimpeiros (independent miners) and work began on part of the lateritic plateau at a place called Garimpo de Cima ("upper mine," later referred to as Trecho Velho, or "old workings"). In June of the same year, emeralds were discovered in a north-south-flowing creek, to the north of the earlier deposit, and a new mine, called Garimpo de Baixo /"lower mine," later referred to as Trecho Novo, or "new workings"l, was opened. After exploring the eluvium, the garimpeiros reached the underlying emerald-bearing rock, and developed the workings accordingly. Since 1981, the deposit has been worked continually with only short interruptions caused by heavy rains or technical problems.

\section{GEOLOGY}

The Santa Terezinha region is part of the Brazilian shield. Middle Precambrian rocks belonging to the Araxá Group (1100-1600 million years old; Barbosa, 1955) are exposed and unconformably over- lain by rocks of the Bambui Group (570-1100 million years old).

The Araxá Group consists mainly of mica schists and quartzites, varying in thickness from a few hundred to almost 2,000 meters. Basic and ultrabasic intrusions and sills occur and appear to be contemporaneous with the sedimentation (Angeiras, 1968).

Sediments of the Araxá Group were metamorphosed during the Uruaçu tectonic cycle (de Almeida, 1971), resulting in north-south trending folds. During the main orogenic phase, syntectonic granitic batholiths were intruded as were alkaline rocks. Pegmatoid granites and granitic pegmatites were emplaced during a post-tectonic magmatic phase. It is in these metamorphosed rocks that the emeralds are found.

Garimpo de Cima-Trecho Velho. These workings, on the eastern side of a flat valley, are reached by an 800 -m-long track that forks from the road of Rio dos Bois. Emeralds were first discovered in surface material southeast of the actual mine. The gem material was later recognized in situ in the underlying talcose schist; it is now being mined via large trenches, pits, and tunnels (figure 3 ).

The eluvial material is a sandy yellow to brown argillaceous soil containing angular fragments of milky quartz and hematite schist, quartzite, and talc schist; limonitized cubes of pyrite; martitic octahedrons of magnetite; and granules of laterite. Many emerald crystals up to $1 \mathrm{~cm}$, heavily stained 


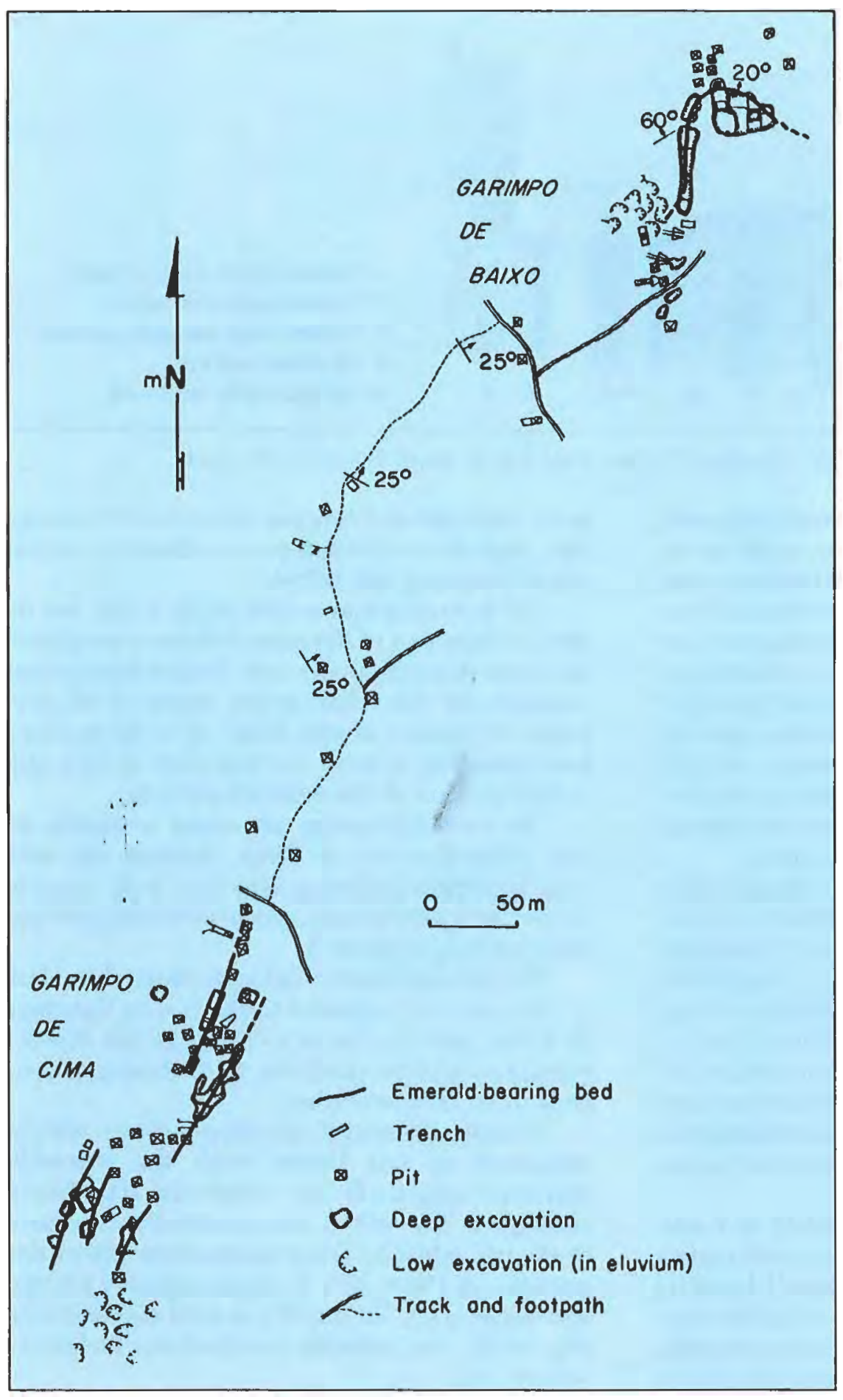

Figure 3. The two main workings, Garimpo de Cima and Garimpo de Baixo, of the Santa Terezinha emerald deposit (as of 1982).

by limonite, have frequently been found in the eluvium.

The finer-grained fraction of the eluvial material consists of the same rocks and minerals described above plus botryoidal coatings of manganese oxides, plates of mica and talc, unweathered pyrite, greenish brown to blackish prisms of tourmaline, colorless zircon, needles of rutile, and orange-red garnet crystals, as well as some monazite and ilmenite, rounded grains of chromite, and, rarely, fragments of light blue beryl associated with small bits of emerald.

The eluvial material, which is now worked out, generally produced emeralds of a lower qual- 


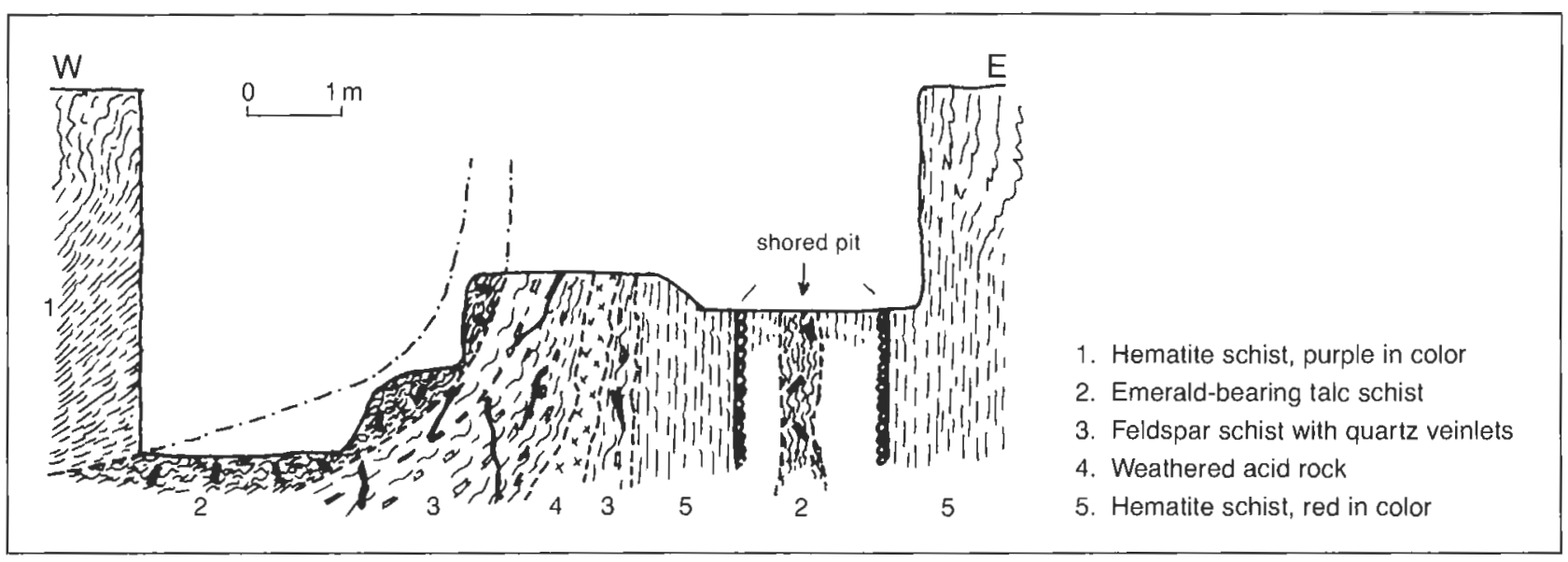

Figure 4. A geologic cross-section of the Garimpo de Cima workings in Santa Terezinha de Goiás.

ity than those found in the unweathered rock. However, studies of eluvial samples made by the Federal University of Rio de Janeiro indicate a correlation between the amount of beryl/emerald in the eluvium and that in the underlying rock. For example, a sampling of the fine heavy fraction of eluvium showed $0.35 \mathrm{~g}$ of emerald per 8 liters of sample. It is believed that this simple method, accomplished by "panning" the surface soil and examining it with a microscope, can be used to determine the lateral extent of the present deposit, and also to identify new producing areas.

At the Garimpo de Cima deposit, there are two distinct continuously mineralized beds of emeraldiferous rock which are called linhas, or streaks, by the garimpeiros. Each is presently worked by deep trenches, pits, and adits, depending on local conditions. Mineralized lenses were also observed, as was a third, relatively short, mineralized bed to the east. Most of the excavations on this third bed are caved in, and are presently abandoned. In all exposures, the wall rocks are subvertical schists that dip north.

The emerald-bearing rock consists of a partially weathered talc schist, pale brownish gray in color and stained by iron oxide. Small limonite nodules result from the oxidation of pyrite crystals. The emeralds always occur in small crystals, either as short prisms or as very cracked pieces, scattered or in groups. They apparently bear no relation to the schistosity or the strilke of the talc schist. A cross-section of the deposit is illustrated in figure 4.

Garimpo de Baixo-CTrecho Novo. This newer mining site lies on the west side of a south-northflowing creek, intersecting the creek at its north end. Quartz-rich eluvium similar to that mined at the Garimpo de Cima had been worked in irregular, shallow excavations prior to discovery of the emerald-bearing talc schist.

The vertical schist strikes north-south, but in the northern part of the mine it forms a periclinal structure that dips to the east. Several pegmatites intersect the talc schist in the region of the pericline. A number of pits, some up to $80 \mathrm{~m}$ deep, have been dug to mine the emeralds in this, the richest portion of the mineralized zone.

The emerald-bearing talc schist is similar to that of the Garimpo de Cima, although the wall rock is slightly different: quartzite beds outcrop in the northwestern pits, as shown in the geologic cross-section in figure 5.

The fact that there is only one mineralized bed in this area, as compared to the two in Garimpo de Cima, may be due to a change in the depositional facies of the quartzite, or to structural controls of Be mineralization.

The emerald-bearing talc schist is almost wholly composed of talc flakes, with the emeralds scattered irregularly but relatively abundantly throughout the rock. A semiquantitative analysis of the talc schist by X-ray fluorescence shows the presence of $1 \%$ to $10 \% \mathrm{Fe}$, approximately $1 \% \mathrm{Ni}$, and traces of $\mathrm{Cr}, \mathrm{Zn}$, and $\mathrm{Rb}$, as well as prominent $\mathrm{Mg}$ and $\mathrm{Si}$. It is probably an ultrabasic metamorphosed rock.

The pegmatites occur as veins or lenses that intersect the emerald-bearing talc schist and associated wall rocks. They are essentially composed of pearly white seriticized and kaolinized feldspar (in large crystals displaying curved cleavage surfaces), associated with some quartz (pink at times) and a few green and blue beryl crystals that have no gem value. Green talc in winding veinlets is abundant. Near its contact with pegmatite, the 
emeraldiferous talc schist includes irregular bands of a grayish mica that has a golden luster similar to that found in the Carnaiba emerald field /Cassedanne and Cassedanne, 1974). Lastly, pockets and veins of quartz, frequently in vugs, commonly occur in the emerald-bearing talc schist and wall rocks.

Origin of the Deposit. It is probable that the emerald mineralization is due to beryllium-rich fluids released by the beryl-bearing pegmatites. The emeralds grew in the talc schist and from the schist incorporated inclusions of chromite, pyrite, and talc. Later tectonic folding caused fracturing of some of the pre-formed emeralds. In general, the deposit is of the mica-oligoclase-beryl type as defined by Smirnov (1977).

Figure 5. A geologic cross-section of the Garimpo de Baixo workings in Santa Terezinha de Goiás.

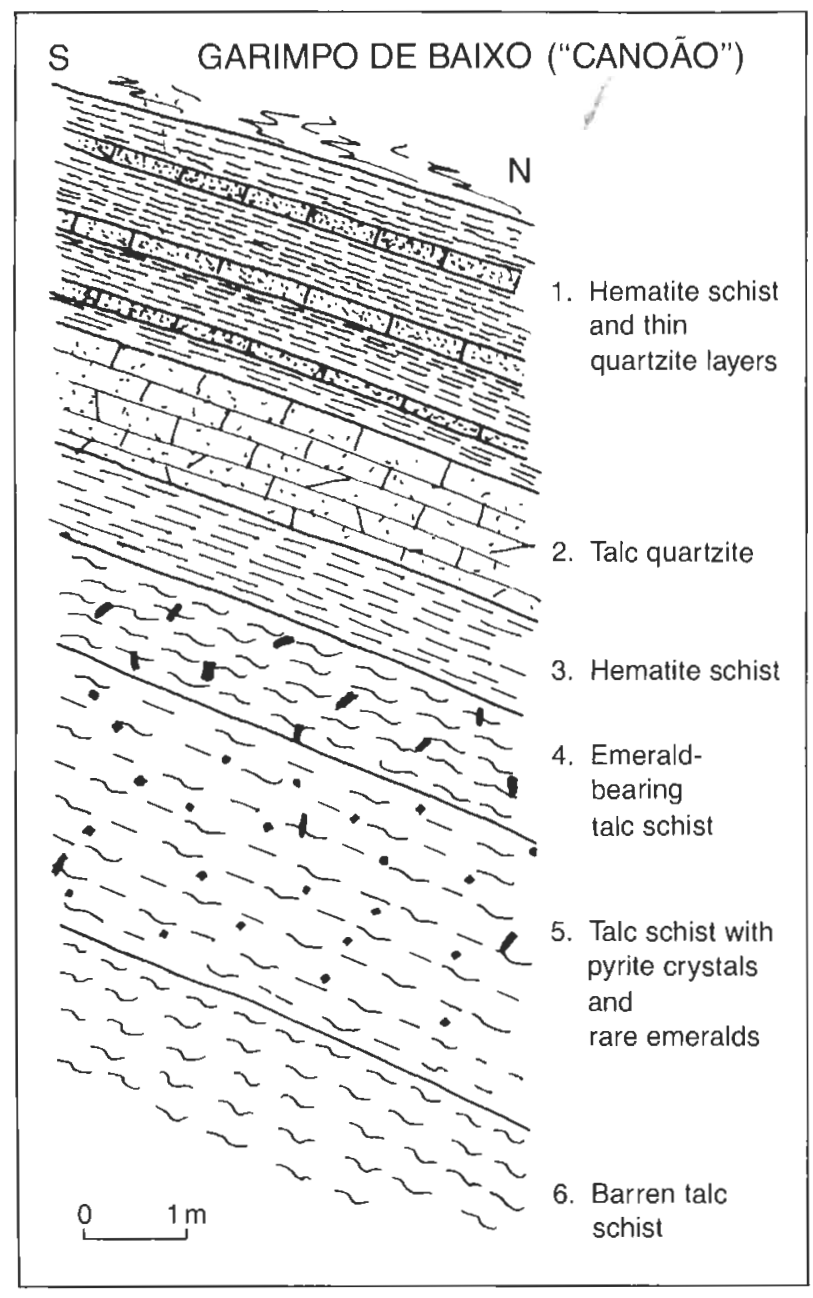

\section{MINING METHODS}

The Santa Terezinha deposit currently is mined only by garimpeiros using primitive methods. Each miner or group of miners works an area that is limited on the surface, usually $4 \times 4 \mathrm{~m}$, but can extend to any depth. This system of dozens of small claims has resulted in the disorganized development of the locality; currently the richest mining areas resemble the "Big Hole" of Kimberley at the height of its production.

The emerald-bearing talc schist is first exposed through trenches dug along the bed; small square pits are then excavated to remove the ore (figure 6). Because the weathered rocks are so unstable, the pits must be shored up with timber. Even so, security is marginal. The risks are increased by the great depths of some pits (most usually extend 10 to $50 \mathrm{~m}$, but some go as deep as $80 \mathrm{~m}$ in Garimpo de Baixol and the driving of adits from the bottom of other pits to recover more of the emerald-bearing rock. Almost all rock removal is done by means of hand tools; blasting is used only rarely, when exceptionally hard rock is encountered.

\section{TREATMENT OF THE ORE}

The recovered ore is treated on the site or taken by truck to washing plants near the mining camp or along the banks of nearby rivers or creeks. Usually, the ore is then concentrated by hand through simple sorting with a coarse sieve. However, a mechanized method is also widely used. With this method, the stockpiled emerald-bearing talc schist is gradually poured into a large vertical barrel called a "blender." The emerald crystals are separated from the soft talc schist as the blender arm rotates the ore in water; the fine material is then carried away by the overflow (figure 7). The process is interrupted periodically so that the concentrate that has settled to the lower part of the blender can be removed. The emeralds are then sorted manually with a sieve.

In recent months, some miners have decided not to process the ore themselves but rather to sell the emerald-bearing rock. Many trucks full of ore for sale now leave the mine site daily. A wheelbarrow with approximately $50 \mathrm{~kg}$ of ore is frequently the unit for a transaction. In August 1983, one wheelbarrow of ore sold for about US\$I50.

\section{GRADE, PRODUCTIVITY, RESERVES}

The grade of the ore has a wide range, from 1 to 6 parts of emerald to 10,000 parts of ore. The aver- 
age yield is 11 carats per cubic meter, which is about 50 times richer than the Belmont emerald mine near Itabira (Minas Gerais). It is generally accepted that a truckload (about 6 cubic meters, or 10 metric tons) yields one kilogram of emeralds; the quality of the emerald usually varies depending on the specific locality from which the ore was mined.

Precise figures on the amount of emerald produced to date are not available, nor has adequate research been conducted to determine the full extent of the deposits. However, inasmuch as many intrusive ultrabasic bodies and sills are known to exist in the central part of the state of Goiás, where berylliferous pegmatites are common, it appears reasonable to suggest that other emerald occurrences may be discovered in the near future. For example, many talc schist outcrops were found during geological prospecting by Shell do Brasil in the townships of Crixás and Santa Marta, about $30 \mathrm{~km}$ from Santa Terezinha.

\section{THE SANTA TEREZINHA EMERALD}

In the talc schist, the emerald frequently occurs as well-formed but stubby crystals, generally less than $1 \mathrm{~cm}$ long. Crystal clusters also occur embedded in the talc, quartz, or mica host rock; often they have no gemological value. The emerald fragments encountered here are probably the result of fracturing that took place during tectonic events following crystallization and are seldom suitable for cutting. Many emeralds that included pyrite during growth have been found to be cavernous where the pyrite has altered, and are stained by iron oxides. The crystallographic forms are usually prisms and basal faces. The prism faces are generally dull, due to a thin coating of talc flakes which are removed by weathering or during the processing of the ore.

The emerald ranges in color from pale to very dark green with a distinct bluish green tone (figure $81 ;$ it is seldom yellowish green. Although in some crystals the color is evenly distributed, more often it is zoned parallel to the prism faces. Occasionally, the cores are colorless. Variation in color along the main axis, however, is seldom seen. The color is believed to be due to chromium.

In terms of cutting quality, many crystals contain numerous cracks, either parallel or perpendicular to the main axis. Inclusions are frequent

Figure 6. Square pits are used to excavate the emerald-bearing ore at the Garimpo de Cima.

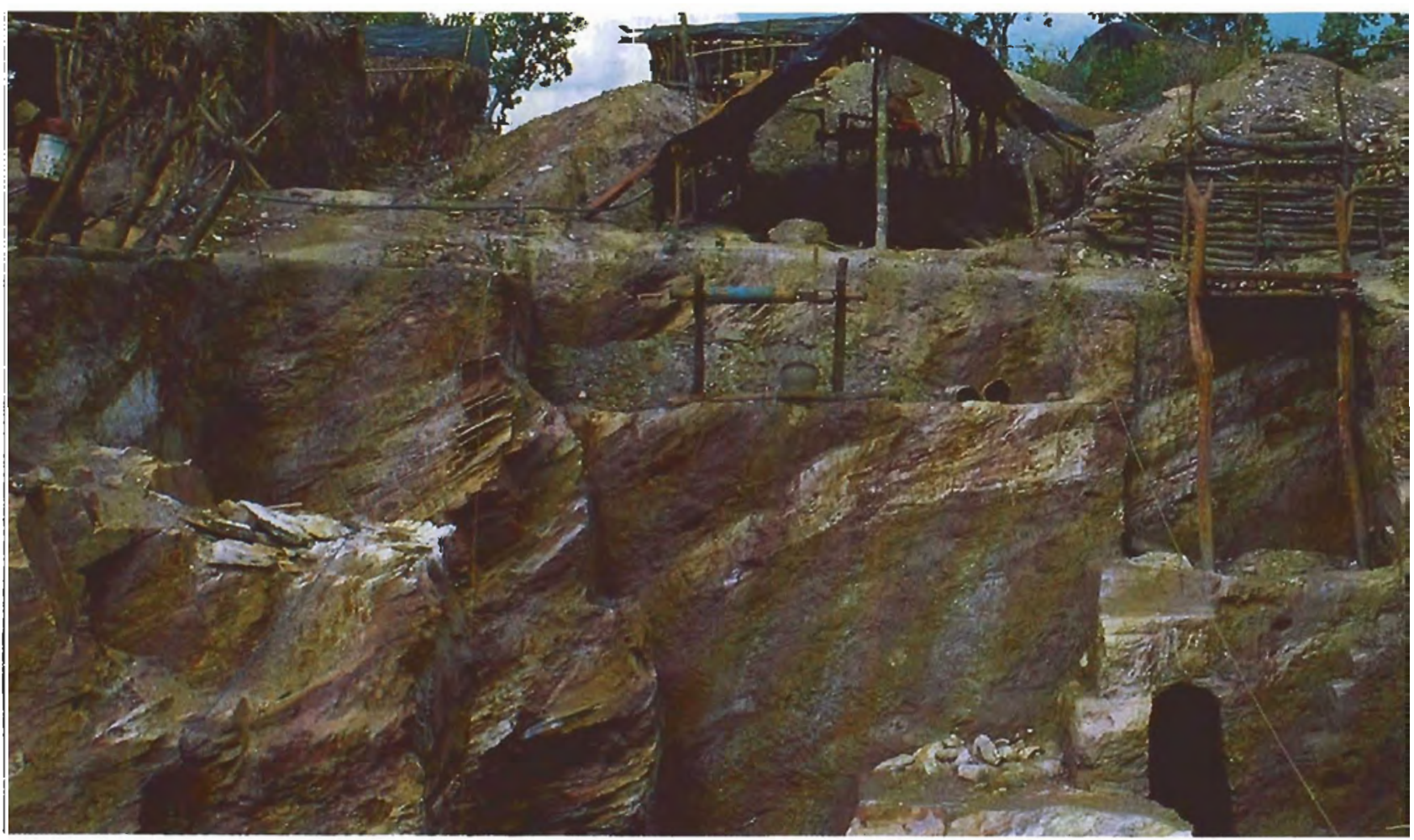




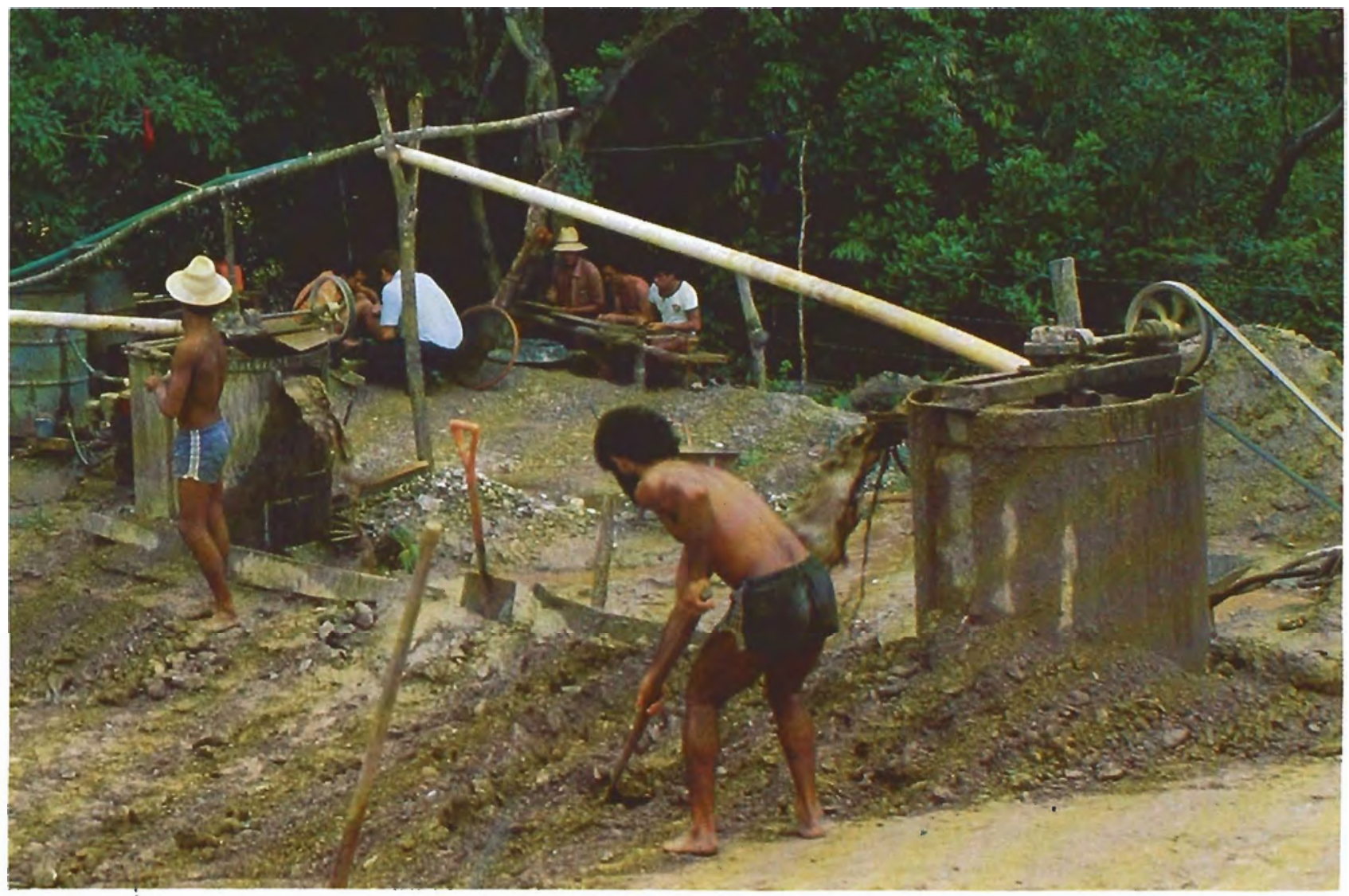

Figure 7. Ore is washed at Santa Terezinha de Goiás using large barrels, or "blenders," to separate the emerald crystals from the soft talc schist.

and scattered randomly. Some of the crystals examined had an almost opaque inner coating (iron and manganese oxides), and others showed a parallel intergrowth with quartz crystals.

The emeralds found in the eluvium, principally from the Garimpo de Cima, were often cracked, and had an unattractive blue gleam. The discovery of the Garimpo de Baixo, and subsequently the general deepening of its workings, has resulted in a higher percentage of relatively clean emeralds with a pleasant bluish green color, as well as the extraction of some fine yellowish green gems. The best faceted gems seldom exceed one carat in weight.

\section{GEMOLOGICAL PROPERTIES}

The physical properties of the Santa Terezinha emeralds are as follows:

- Specific gravity: $2.70 \quad(+0.015$; crystals included with pyrite may have an S.G. as high as 3.05)

- Refractive indices: o $=1.580( \pm 0.001), \mathrm{e}=$ $1.588( \pm 0.001)$
- Birefringence: 0.008

- Pleochroism: greenish dark blue/yellowish pale green

- Fluorescence and radioactivity: none

- Chelsea filter: inert to pink; usually the color is unevenly distributed

- Absorption spectra: sharp lines at 6920 and $6950 \AA$, and partial absorption between 6000 and $6350 \AA$ and between 4000 and $4450 \AA$.

Crystals with few or no inclusions are perfectly transparent. The most important inclusions are pyrite, chromite, talc, and calcite, although other minerals have also been observed, as described below.

Pyrite (and limonite pseudomorphs after pyrite) is the inclusion most common to the Santa Terezinha emeralds. The pyrite occurs as sharp or slightly rounded cubes, isolated or in groups (figure 9). Numerous minute crystals may form tiny clouds.

Chromite is present as black rounded crystals or in octahedrons up to $2 \mathrm{~mm}$ wide. The large individual crystals are isolated, and the small ones 
Figure 8. An assortment of emerald crystals from Santa

Terezinha. The crystals average approximately $1 \mathrm{~cm}$ in length.

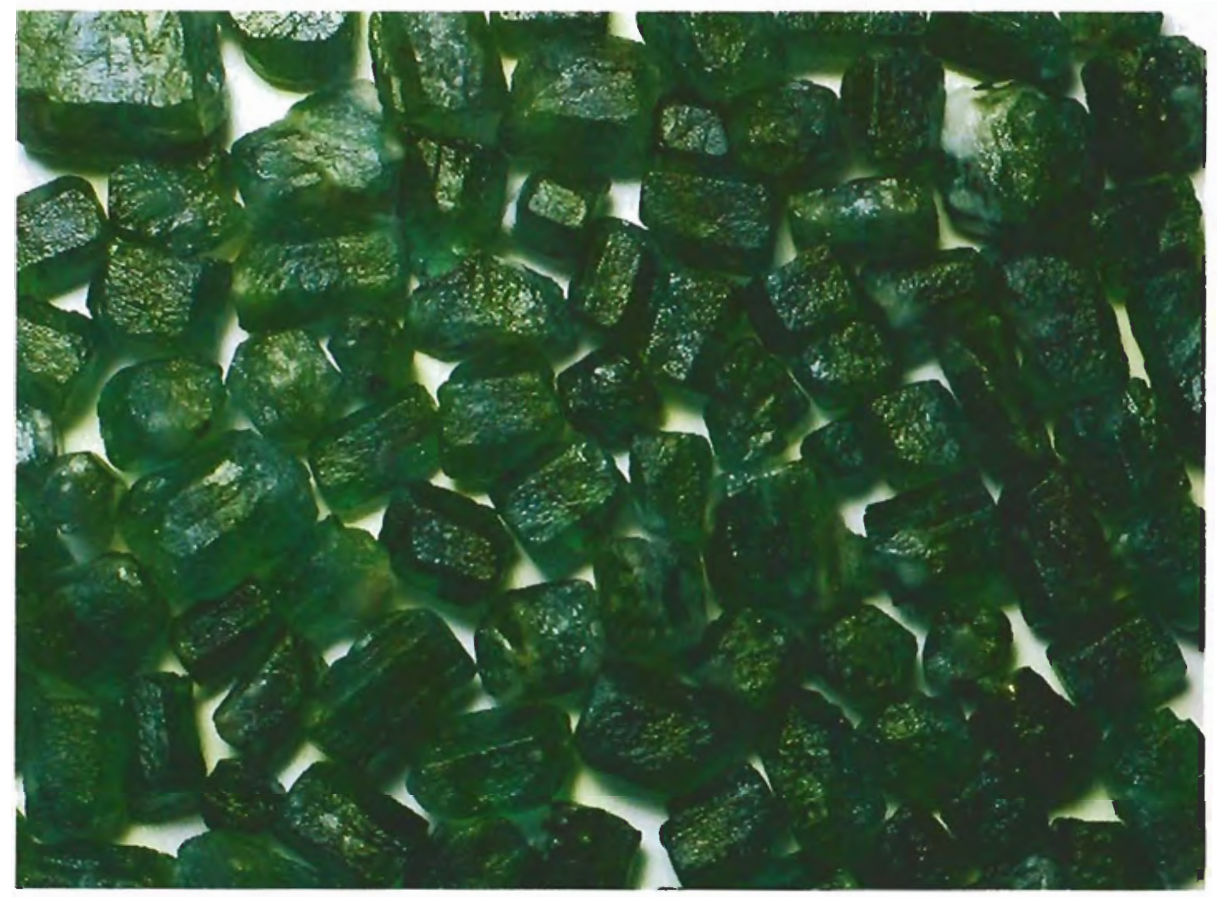

form irregular clouds or films and trails parallel to the basal faces (figure 10). Semiquantitative analysis of the chromite by X-ray fluorescence showed approximately 0 to $1 \%$ zinc and traces of manganese and nickel in addition to iron and chromium.

Talc flakes, generally white and silky, are so abundant in some emeralds that they make the crystal appear cloudy. The flakes are sometimes regularly oriented at $60^{\circ}$ on the main axis of the emerald crystal.

Calcite occurs as transparent to translucent rhombohedrons and as irregular pinpoint-like flakes observed singly or in groups. Analyses have shown

Figure 9. A well-formed pyrite inclusion in emerald from Santa Terezinha de Goiás. Magnified $45 x$.

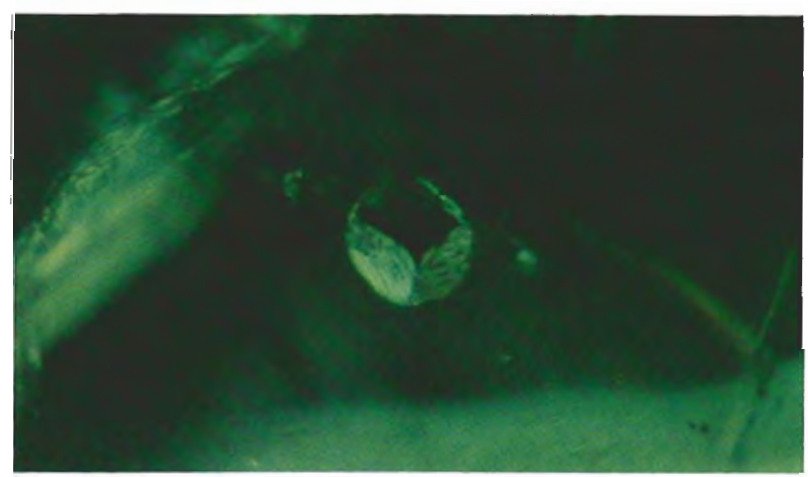

that some of the calcite contains traces of magnesium, suggesting a solid solution toward dolomite, another carbonate.

Among the other inclusions observed are hematite, which occurs as flattened reddish translucent crystals scattered throughout the emerald; ilmenite, which has been observed in plates resembling the typical inclusions of certain Minas Gerais aquamarines; and goethite, which we have tentatively identified in the brownish yellow parallel fibers that have been encountered in a very few emeralds. Fingerprints formed by calcite or

Figure 10. Chromite inclusions in emerald from Santa Terezinha de Goiás. Photomicrograph by John I. Koivula, magnified $50 \times$.

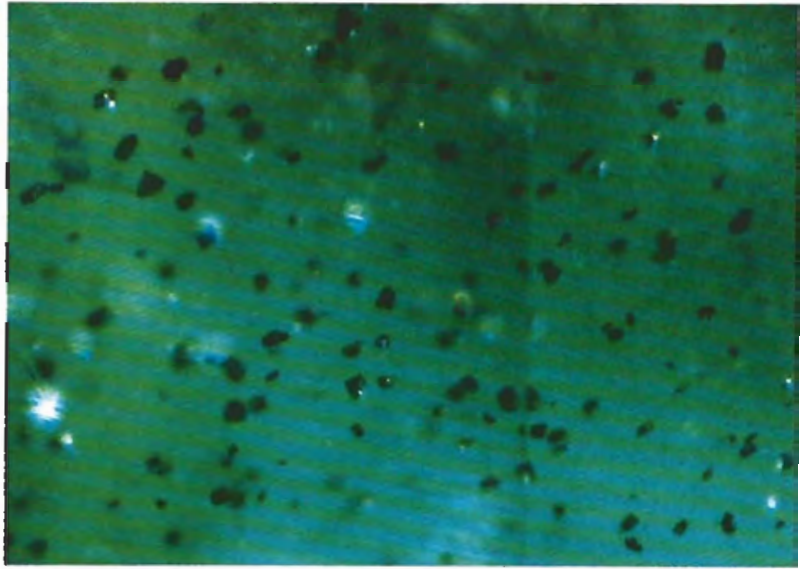


limonitized pyrite also occur, as do two-phase inclusions.

In contrast to other emeralds from Goiás, for example Fazenda das Lages, the Santa Terezinha gems are cleaner and more transparent. Rutile needles have been observed only in emeralds from the Fazenda das Lages deposit (Sauer, 1982).

\section{CONCLUSION}

Presently Santa Terezinha de Goiás is the main active producer of emeralds in Brazil. The emeralds are recovered from a $\mathrm{Cr}$-talc schist layer intersected by Be-bearing granite pegmatites. The gems are small, yet of good quality. Chromite and pyrite are the most prominent inclusions, with calcite observed in minor amounts. Deep reserves that can be reached by pit mining promise another few years of production. It is also probable that there will be new finds in the vicinity.

\section{REFERENCES}

Angeiras A.G. (1968) A faixa serpentinitos da regiāo central de Guiás. Anais Academia Brasileira de Ciências, Vol. 40 (suppl.), pp. 129-136.

Barbosa O. (1955) Guia das excursões do IX Congresso da Sociedade Brasileira de Geologia, Note No. 3, Sociedade Brasileira de Geologia, Rio de Janeiro, Brazil.

Cassedanne J.P., Cassedanne J.O. (1974) Note sur la mine d'émeraude de Carnaiba. Association Française de Gemmologie, Bulletin No. 40, pp. 4-8.

de Almeida F.F.M (1971) Geochronological Division of the Precambrian of South America. Revista Brasileira de Geo ciências, Vol. 1, No. 1, pp. 13-21.

de Souza M.S.P., Zalán P.V. (1977) Ocorrēncias de cassiterita e wolframita ao Sul da Serra Dourada (Goiás). Mineração e Mélalurgia, No. 385, pp. 4-9.

Gonçalves A.D. (1949) As Pedras Preciosas na Economia Nacional. Gráfica Olímpica Ed., Rio de Janeiro, Brazil.

Leinz V., Leonardos O.H. (1959) Nota sobre as esmeraldas da Fazenda das Lages, Itaberai, Goiás. Gemologia, Ano IV, No. 16 , pp. $7-14$.

Sauer D.A. (1982) Emeralds from Brazil. International Gemological Symposium Proceedings, Gemological Institute of America, Santa Monica, CA.

Smimov V.I. (1977) Ore Deposits of the USSR. Vol. 3, Deposit of Beryllium. Pitman Publications, London, England.

\section{A PACKAGE DEAL from GEMS \& GEMOLOGY}

A complete set of the four information-packed issues published in 1983 is now available. For $\$ 19.50$ (in the U.S.) or $\$ 22.50$ (elsewhere), you can have over 250 pages (with more than 200 color illustrations) of the most important articles, lab information, and news in gemology today.

Highlights of the 1983 volume include articles on Kashmir sapphire, Burma ruby, the oil treatment of emeralds, Ramaura synthetic rubies, the diamonds of Harry Winston, Art Deco jewelry, and induced fingerprint inclusions, among many other topics. Featured in every issue are the invaluable Gem Trade Lab Notes, Book Reviews, Gemological Abstracts, and Gem News sections, with a comprehensive index completing the volume.

Or save $\$ 4.00$ and purchase both the 1982 and 1983 volumes (eight issues) of GEMS \& GEMOLOGY for only $\$ 35.00$ (U.S.) or $\$ 40.00$ (elsewhere). With the 1982 volume you have articles on the heat treatment of corundum, the identification of jade, artificial coloration of diamond, the gems of Pakistan and Sri Lanka, as well as reports on new diamond cuts, synthetics, and identification techniques. The 1982 volume is also available separately for $\$ 19.50$ (U.S.) or $\$ 22.50$ (elsewhere).

To order one or both sets, just send your check or money order to:

\section{Back-Issues Department \\ GEMS \& GEMOLOGY \\ 1660 Stewart Street \\ Santa Monica, CA 90404}

Please allow 4 to 6 weeks for delivery in the U.S., Canada, and Mexico; 8 to 10 weeks for delivery elsewhere. Be sure to specify which set or sets you want when you order. 